Review of

ECONOMICS

and

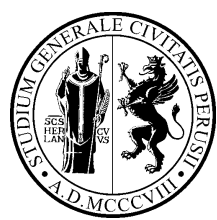

www.rei.unipg.it

\title{
Institutions, Natural Resources and Economic Growth in the Modern Age, the Case of Dogana delle Pecore in the Kingdom of Naples (XV- XVIII Centuries)
}

\author{
Alberto Guenzi \\ Dipartimento di Economia, \\ Università di Parma
}

\author{
Roberto Rossi $\mathrm{i}^{\bowtie}$ \\ Dipartimento di Scienze Economiche e \\ Statistiche, Università di Salerno
}

\begin{abstract}
The trade of wheat and wool has been one of the economic pillars of the Kingdom of Naples during Modern Age. Since Romans times the production of these commodities - in the continental part of the Kingdom - has been regulated by the trashumance system that coordinated the flow of sheep on Puglia's Tavoliere lands. We would highlight the role exercised by the institutions as development agents. In particular, the paper would demonstrate that the new institutions introduced by the king Alfonso I of Aragon were the main driver not only of trashumance but of the entire economic framework of the kingdom. A simple analytical model based on the complementary dynamics of pasturing and wheat production shows the results of the functioning of the new system. The results challenges the negative interpretation of the trashumance led on by the Neapolitan Reformers (illuministi) at the end of XVIII Century and widely absorbed by historians in the XX Century.
\end{abstract}

JEL classification: N5; N530; P160;

Keywords: agriculture, institution, development

We would like to thank the two anonymous referees for their helpful comments. The authors also would like to thank Mario Menegatti for his suggestions in the building of the model in Section 3. The usual disclaimer applies.

\footnotetext{
$凶$ Corresponding Author. Address: Dipartimento di Scienze Economiche e Statistiche, Università di Salerno, Via Giovanni Paolo II, 84084 Fisciano (Salerno), Italy (Phone: +39 089963425 Email: rrossi@unisa.it)
}

\section{Recommended Citation}

Guenzi, A., Rossi, R. (2014). Institutions, Natural Resources and Economic Growth in the Modern Age, the Case of Dogana delle Pecore in the Kingdom of Naples (XV-XVIII Centuries). Review of Economics and Institutions, 5(2), Article 3. doi: 10.5202/rei.v5i2.115. Retrieved from http://www.rei.unipg.it/rei/article/view/115 


\section{Introduction}

This paper aims to investigate the role of institutions as development agents. In particular it studies the reform of agriculture in the Kingdom of Naples in Southern Italy, between the fifteenth and sixteenth centuries. We intend to demonstrate that the new institution introduced by Alfonso I of Aragon was the principal driver not only of transhumance but of the entire economy of the Kingdom. The positive appraisal of the new institution challenges the negative interpretation of the end of the eighteenth century, expressed by Reformers of the Neapolitan school (Illuministi), and subsequently adopted by historians in the twentieth century. The paper is articulated in four parts. The first illustrates the reform process under the Aragonese, with the introduction of a new institution appointed to coordinate transhumance on a huge scale. The second part analyzes the key element of the economic model, based on the complementary dynamics of pasturing and wheat farming. The third part presents two models that illustrate fundamental aspects of the agriculture-pasture system in terms of management of land and the impact on this management of variations in the price of wool and wheat. In the fourth part, we point out some conclusions.1.

\section{Historical Background}

Around the mid-fifteenth century, in Southern Italy, excluding Sardinia and Sicily, an institution arose with a new management model for territorial resources. The system was focused on Foggia, the main center for trade in wheat and wool. The institution was called the Dogana della mena delle pecore di Puglia (Puglia Customs-House for the toll of Sheep). The sheep came down from the mountains of Abruzzo in autumn to the warm plains of Puglia, where they yearned, and in May returned to the highlands (Swinburne, 1783, pp. 139-144). In 1448, Alfonso I had restored a system previously tried by the Normano-Swabians and the Angevin-Plantagenet dynasty, modified by a new model of governance: "being desirous of avoiding every shadow of coercive legislation and tyranny in the reestablishment of them" he negotiated with the grazers and sheep-owners of Abruzzo, and the land-owners of Puglia, stipulating an agreement of evident advantage to the Crown and profitable to themselves. The King provided the shepherds with winter pasturage for seven months, and a convenient road, called the Tratturo, for the transfer and shelter of the flocks; freedom from all royal and local tolls, protection from all disturbances, and credit.

Not possessing sufficient land for pasturing the huge flocks expected from Abruzzo, the Crown purchased from Puglia landowners as much as

${ }^{1}$ Units of measure used in the paper: land 1 carro (pl. carri) $=24,5$ hectares; wool 1 pound $=343 \mathrm{~g}$;; wheat 1 tomolo $(\mathrm{pl}$. tomoli) $=40 \mathrm{~kg}$. 
was thought to be needed. If it was not enough, the Crown had the power to compel its subjects to lease any grassland that might be needed to make up for the deficiency. For these leases, the King agreed to pay in perpetuity 13.912 ducats a year, at its own risk and accepting any losses. These royal pastures were identified and circumscribed, and were known by the name of Tavoliere. They extended for sixty miles in length, thirty in breadth, and were divided into 23 old and 20 new lots, capable of feeding a total of 1.200.000 sheep. In return for all these services on the part of the King, the shepherds of Abruzzo made a commitment, also in perpetuity, to bring their sheep from the mountains each year, to acknowledge the jurisdiction and powers of the King, and the penalties imposed by the Dogana, and to pay a tax based on the number of animals. The shepherds agreed to sell their wool, and any other commodities produced during their winter residence, only in Foggia. By way of compensation, no wool in the kingdom could be brought to market until the wool in Foggia had been sold.

The literature dealing with the period generally overlooks or underestimates the importance of this institution. Many have suggested that the reform carried out by Alfonso was nothing more than a version - on a smaller scale - of the Mesta Castigliana and was designed solely to raise tax revenues. (McNeill, 1992, p. 92; Pinto-Correja, 2004, p. 146; Grigg, 1976, p. 136; Carrier, 1932, pp. 44-55). Even Benedetto Croce considered the customs an expression of the subjugation of Naples to Spanish rule (Croce, 1917, p.43). According to this view, Alfonso I only restored a pre-existing system for the organization of transhumance, applied in previous centuries by the Swabians and Angevins. The poor ability to innovate derived from the re-presentation of an old model of governance, with the addition of some features from the Mesta; the result was a fiscally oppressive system preventing the development of agriculture into an efficient farming system.

\subsection{The Role of the Dogana delle Pecore Compared to Spanish Mesta}

Our point of view is radically different: in our opinion, the Mesta and Dogana are different and in many respects alternative models, and the innovations introduced by the Aragonese constitute a thorough and irreversible reform of the system of agriculture, leaving the Swabian-Angevin system behind. With regard to the supposed similarity between the Mesta and Dogana, significant recent studies have criticized the entirely negative opinions of Klein on the Spanish institution (Klein, 1920); in reality the Mesta was an economic institution which efficiently carried out the function of "zoning commissioner" (Nugent and Sanchez 1989), reconciling the needs of farming with those of local institutions (Ekelund et al., 1997), and managing the exchange of factors of production (Drelichman, 2009). Having said this, the difference between the Mesta and Dogana seems altogether evident in the 
management of the territorial resources used to guarantee the temporary migration of millions of sheep for pasturing purposes. Put simply, Spanish breeders could move and pasture sheep anywhere with the exception of the areas reserved for the " 5 forbidden things" (arable land, pasture, vineyards, orchards and meadows for threshing) (Ruiz Martin, 1998, p. 26), and could lease land for grazing directly from landowners (Marin Barriguete, 1998). The Mesta was essentially a private institution for the production of an important commodity, giving rise to trade, which was taxed (Cazzola, 1998).

In concrete terms, the Mesta crystallized the existing situation, i.e. it sanctioned the privileges that allowed migrant flocks to pasture on land owned mainly by the Crown and the most important owners of cattle (the largest religious orders: Santiago, Calatrava, Alcantara and the powerful landowning Castilian and Aragonese aristocracy), using a resource (grazing land, meaning land) that was practically unlimited and hence enabling expansion of animal husbandry, without adversely impacting on the complementary and rival use of land for the production of wheat (Garcia Martin, 1990). The real difference with the Mesta consisted in the way the rights of ownership were used; in Spain they were negotiated face to face by owners and livestock farmers, which produced evident difficulties for trade and lacked coordination and the ability to monitor results. These problems were overcome by the Dogana system which functioned efficiently in Southern Italy for several centuries through its in-depth organization of all the activities of CPR by means of the institutional support given to the management of common property rights (Forni, 2000, pp. 34-36).

The supposed continuation of previous experiences and hence lack of innovation of the system is also open to question. Several decades ago, (Ryder, 1976, p. 362) noted that "In the administration of the grazing lands of Puglia, Alfonso introduced a radical reform". The innovative nature of the institution derived from the decision to take direct action in relation to the property rights of the barons, forbidding them to sell grazing land directly to shepherds. This was achieved with a mixture of the carrot and the stick: during the months of autumn and winter the land passed under the direct control of the Dogana, which allocated it to the flocks; in exchange barons could count on high, constant and certain revenues. When all is said and done, the system worked by imposing an agreement on the two parties involved, eliminating disputes between the landowner and the cattle owner leasing the land.

The in-depth research carried out by Marino shows that the Dogana was an institution that introduced a new experimental form of governance: "The early modern state's support for pastoral economies responded to a rational economic model" (Marino, 1998a, p. 872). The American researcher sees in the solution to the problem of coordination the decisive feature of the new system. Unlike the Mesta, which could count on endless land, the Dogana had grazing land during winter of 15.439 carra, about 380.000 hectares, and 
Figure 1 - Map of Tavoliere realized by P. Di Cicco and E. Caruso, re-elaborated by S. Russo and M.C. Nardella

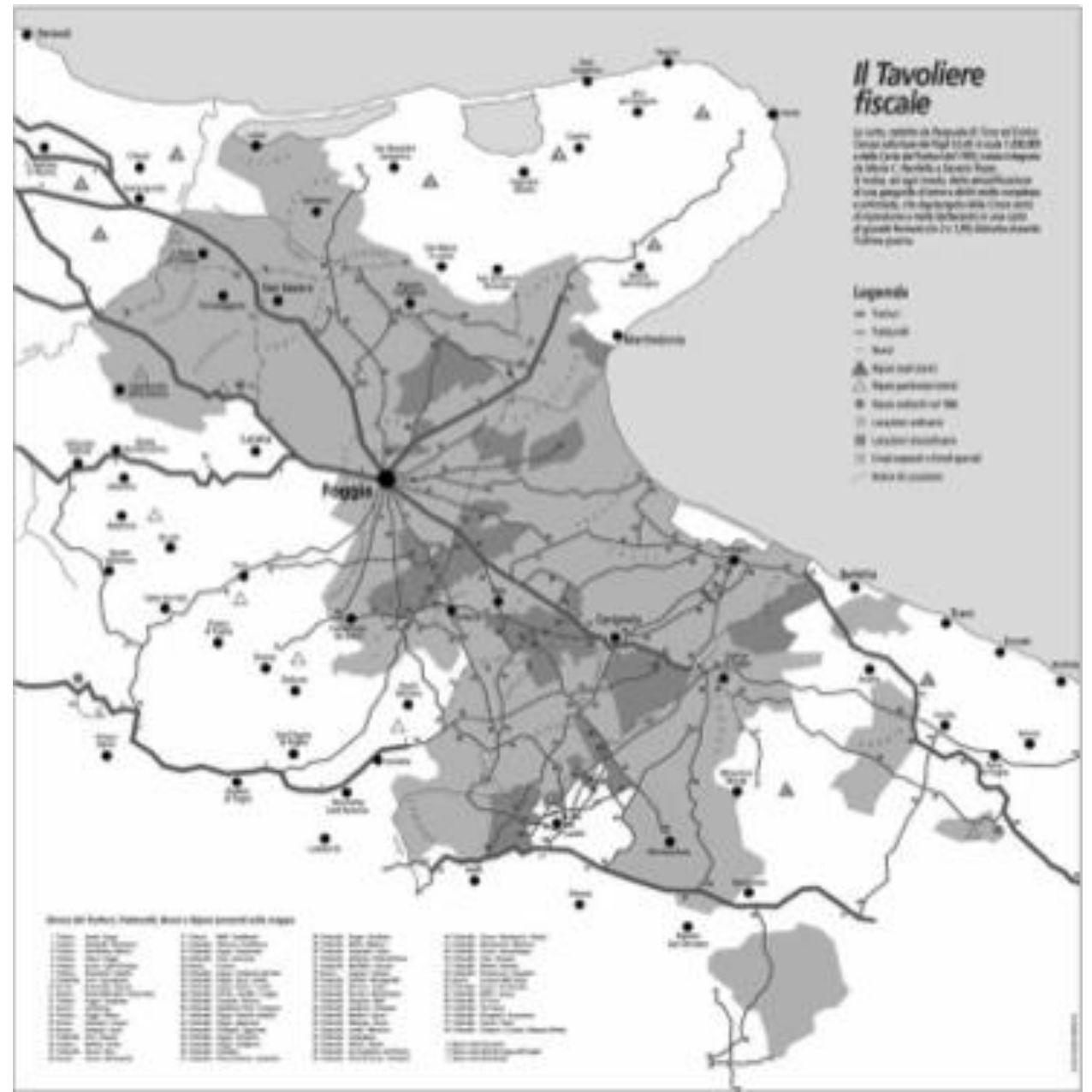

an ecological limit of 2,5 milion sheep. In particular, the land of Dogana was divided between terre salde (about 212.000 hectares) only used for grazing and terre di portata (about 153.000 hectares) normally used for agriculture, but partially used for grazing (in the half usually subject to rest) and, finally, about 15.000 hectares of accessory lands (Del Treppo, 1984).

The lack of available land imposed complex coordination activities: twice a year, millions of sheep and thousands of shepherds needed to be moved from between 200 and 500 kilometers over a period of no more than twenty days. The flocks moved along the wide grassy paths with areas to the side for overnight stops. The migration needed to be scheduled according to a very precise calendar: between 15th September and 15th October the flocks reached the border between Abruzzi and Puglia, i.e. the river Biferno. From 16th October to 1st November they entered in three huge areas adjacent 
to the Tavoliere and called areas of general rest (Saccione, Gargano and Murge). From 2nd to 25th November, the sheep had to follow predetermined routes to the winter grazing lands allocated: each flock had one large location, divided into grazing land and land for cultivation: the land for crops was divided by farmhouses whilst the grazing land was separate. An example shows the complexity of the system: imagine a flock of 300 sheep at the beginning of September in Sulmona in Abruzzo. The shepherd and his assistants needed to move the flock for about two months, pending allocation of the area for winter grazing, and then to occupy the designated land in the Tavoliere. The land was allocated according to its fertility and the size of the flock. Next to the fenced off areas were the fields with farmhouses, only some of which were sown. The sheep could graze in the restring areas: "The animals provided manure for the cereals, and improved the arable production rate". This meant that crop farmers and livestock farmers needed to cooperate (Black, 2001, p. 54).

\subsection{The Dogana delle Pecore as a Territorial Resources Man- ager}

In the Southern Italy, Puglia transhumance cannot properly be examined except as a part of the overall regional farming pattern. It was necessary to provide the shepherds with an efficient order of relationships and social and economic organization (Cleary and Delano Smith, 1990, p. 24) Essentially, the Dogana may be considered an example of a sophisticated partnership between those having more stock than land and those having more arable land needing manure than animals to provide that vital commodity. (Kleibenz, 2004, pp.1091-1092). In order to function properly, the model of transhumance adopted by the Dogana needed to solve the problem of coordination: each flock was allocated in a portion of land corresponding precisely to the need for grass (quality and quantity). Too little space would decimate the stock and too much would limit the ability of the system to sustain the total number of sheep. The form of management of territorial resources exercised by the Dogana was far deeper and more complex than any other European or Italian system of transhumance - in other words it was a much more advanced system of management than existed anywhere else. The presence of a state economic institution appears to have been absolutely necessary, given the number of actors involved directly and indirectly, the volume of production, and the number of trades nationally and internationally. The Neapolitan reformers criticized the Dogana system for the disastrous participation of the state but, in fact, it was vital and necessary in order to guarantee the functioning of markets. The main instruments operating within the framework of the Dogana system involved a multiplicity of markets: the tax imposed on shepherds (fida) was only partly taken by the tax authority; a considerable portion was used to lease land not 
owned by the state. The fida was a tax derived from affidamento, i.e. the institution by which the Crown was obliged to provide grazing land, making transhumance for pasture obligatory. The Crown received the fida but did not limit itself to allocating (distributing) grass, but also protected the flocks and shepherds, exempting them from any other taxation, excise or duty on products from the breeding of sheep, regulating the wool market (with the aim of reducing transaction costs).

The allocation of grazing land determined the production of wool, sold at the Foggia Trade Fair (or Market), within the framework of a network for international trade; the sheep also contributed to improving the yield of crops and wheat for the rationing system of the capital and for export. The practice of providing a public reference price (voce) for wool and wheat helped trade and the stipulation of futures contracts, the main instrument of financing for companies. In this way a model of "good government" was constructed, seeking a temporary and unstable balance because conflicts remained as did the elements of uncertainty impacting on production (Ciccolella and Guenzi, 2008)

A recent book makes an in-depth investigation in the new Aragonese system for the first time. The reform of pasture lands was part of a more general reorganization of the economic model, with a coordinated effort to improve trading: "the Aragonese rulers secured two prerequisites for the integration of the domestic market: territorial unity and tax free-trade within the Kingdom" (Sakellariou, 2012, p. 248). The elimination of taxes for internal trade was made possible by the shift from indirect to direct taxation: From 1440 the state could afford to take measures reducing trade tolls, because thanks to Alfonso's fiscal reform, the bulk of the state revenue came from direct taxation. In particular the previous tax on each head of the family (fuoco) imposed directly as an extraordinary measure, became a regular annual tax. The resources collected enabled a steep reduction of import and export duties, allowing important commodities such as wool and wheat to join a network of international exchange.

In relation to territorial unity, Alfonso I used precisely the new institution to overcome the specific powers of the barons which were manifested in the form of taxation. In effect, the services and goods offered directly by the Dogana included free and safe passage, sufficient pasture at uniform (without favoritism), state-established prices, and expeditious civil and criminal justice. These direct benefits were in addition to the action of the Crown in terms of facilitating trade such as the decision to make Foggia a specialist market open to foreign traders for the sale of wool, and to establish a reference price for wool and wheat for everyone involved in the production of goods under the pasture and transhumance system. The price of wheat was regulated by the voce of San Giovanni Rotondo which set a value allowing for the stipulation of forward contracts, providing credit to small traders. It was a sort of public price which regulated a futures market in which cred- 
itors forwarded loans in money and producers paid back in kind. The voce included the interest. As early as the sixteenth century, the price alla voce of San Giovanni Rotondo for wheat had become reference price for the entire Kingdom (Marino, 1998b, p. 143). The Aragonese improved the performance of the commercial circuit of the realm partly through the reorganization of the system of weights and measures, and the monetary system.

Overall, these measures lowered transaction costs and prompted production specialization in the various regions of Southern Italy: The reorganization of the custom house (Dogana) is a brilliant example of how a strong central government could curb centrifugal tendencies in the provinces, enhance state coercion and extend royal prerogatives and jurisdiction" (Sakellariou, 2012, p. 276).

The implementation of the reforms should not be considered the result of a merely top-down process, imposed from above. On the contrary, it was a sophisticated political operation which sought to enroll the support of the barons and shepherds by using the carrot and the stick, obligations and incentives. For example, the obligation on shepherds to take their flocks to the Tavoliere was compensated by the certainty of finding suitable grazing land for the sheep, the ability to sell their wool on the Foggia market, and the protection provided by the state during the period of migration and grazing in Puglia. The barons, no longer allowed to exact private rights of passage, maintained their ownership of the grazing land, with the Crown limiting itself to obliging them to lease the land for 6 months a year, a revenue that was guaranteed and of the highest order.

The way the Aragonese reformed the Dogana has one extremely important feature: the transformation of the economic institution produced positive effects because the changes impacted not only on the de jure political power (derived from the institutions) but also on the de facto political power held by groups representing concrete interests. Without this repercussion on the organization of power, the reform would have had only minimal effects. (Acemoglu and Robinson, 2010).

The above considerations refer to the fulcrum of the new customs-house system: to reconcile the diverging interests of producers and shepherds, whilst at the same time guaranteeing greater efficiency in the economic model based on wheat and wool. Within this framework, land was the rare resource historically disputed by the two groups. Various options could have been chosen to solve the conflict; the first would have been to adopt the exclusive use of farmland for grazing land in the Tavoliere and for the cultivation of cereals. The second would have been to irreversibly separate grazing land from crops. Neither of these, however, would have improved the overall efficiency of the system. What was needed was a solution that increased the output of wheat and, at the same time, gave the largest amount of grazing land to sheep, without expanding the land available. In this way, the potential conflict between the shepherds and crop growers was resolved to their mutual advantage. 
The Aragonese institution, which showed from its inception an understanding of the opposition between farmers and shepherds, proved able to take on the role of governor, using the conflict to introduce a new organizational model, over time also introducing innovative processes: "a complementary and contradictory modus vivendi between wheat and wool provided rural society with a cyclical rhythm of "ordered anarchy (Marino, 1998a, p. 879). The change in the economic institution in this case started off an innovative process that was destined to last over time; but the continuous nature of the innovative process would not have been guaranteed by the contract alone (even with its subsequent amendments). The result was obtained by virtue of the ability of the Institution to exercise leadership and to demonstrate to the shepherds and farmers (and wheat and wool merchants, barons, Universities and even the Sovereign) that their fortunes were inter-dependent and their destinies bound up over time one with another. This provided each actor with a sense of his role. In other words, the interdependence defined a group whose members took on collective responsibilities (Lewin, 1948). Over time, the Dogana managed a situation in provisional and precarious balance which required continual small adjustments: "beyond the equilibrium between arable and pastoral resources, institutional arrangements and market relations played a crucial role in striking a balance between cereal and livestock farming" (Sakellariou, 2012, p. 271). In order to provide a transparent forum to mediate the tensions between farmers and shepherds, as early as the second half of the fifteenth century, measurements were made leading to a complete cadastral survey; the territory of the Dogana was measured to the utmost precision in order to record the actual use of land "in real time".

The monitoring of the use of land was the basis for an administrative procedure named reintegra (reintegration) which aimed to re-establish relations between grazing land and farmland for cereals (Russo and Salvemini, 2007, p. 110). Nonetheless, the process of ascertaining the abusive occupation of state-owned grazing land or the tracks used by shepherds during the transhumance did not follow the blind logic of recovering for the state what had been unlawfully taken over. The Crown was not interested in merely recovering the grazing land, eliminating any crops unlawfully sown and cultivated, but also wanted to use the reintegration of the land as a further bargaining chip in the mediation between farmers and shepherds. The territory was not only measured but also valued in terms of its fertility in order to assess the amount of grass the grazing land could provide, and hence the size of flocks that could be grazed on the land (Violante, 2009, p. 78). This was accompanied by further elements in the set-up of the new organization: in addition to the improvements in market organization and impact of the increasing demand of wool, a very important factor was the agricultural management of Puglia, which depended on the close relationship between arable land and sheep farming for soil replenishment.

Thanks to the actions of the Aragonese, the agricultural system was 
transformed in what could be justifiably termed a proto-capitalist system. The organizational model of crop farming was defined and, in some way, regulated on state-owned land; the same model was adopted for the land owned by the barons which were managed on a stable basis by the Dogana. The model was based on a 4-year rotation, an intensive preparation of the soil in the second fallow year, a low quantity of seed for each unit of land (and a high yield of crop for each seed). The second element relates to how the fields were managed. The production of cereal on a massive scale can only be called a capitalist enterprise (Renda, 1974, p. 97). Just as management was separate from ownership, so organizational management and technical management (crops, oxen and horses for ploughing, transport and threshing, the need to obtain and renew capital) were separate. Farms exercised a strict division of labor and salaried work prevailed.

Within the new configuration, a system was found to increase the yield of crops without diminishing the amount of grazing land available. This involved regular fertilization by sheep manure: as illustrated in detail below, a four-year cycle integrating arable farming with sheep grazing increased the productivity of the Tavoliere, making crop yields from seeds quite unique for the period, 1:7, sometimes as high as 1:10. This was the aim of the reform: to optimize yield through complementary activities. Data for the second half of the fifteenth century and the sixteenth century show the success of the idea: wool and wheat production both increased as did the export of these products. Transhumance organized on the basis of the innovative Aragonese model was an all-round success: "no other region specialized in animal husbandry as much as the complex of Abruzzo and Puglia, although everywhere an advance in livestock farming can be observed" (Sakellariou, 2012, p. 427).

\subsection{Grazing, Manuring and Productivity}

Land that lay fallow was considered as pasture. In our opinion this was a central question, whose importance went beyond only aspects of economic advantage. The practice is similar to the experience in England. Simplifying somewhat, it can be argued that the grazing land management system of the Tavoliere was derived more from northern Europe than Mediterranean systems. If proven, this hypothesis would radically change the judgment of historiography which considers the grazing systems of the Mediterranean an obstacle to the development of advanced agriculture, as practiced in northern Europe (Klein, 1920). In England, opening up wheat fields to manuring by sheep dates back to faldage, an ancient landlord's right: "an ancient privilege of setting up sheep-folds, or pens, in any field within their manors, the better to manure them" (Mordant, 1761, p. 85; Bailey, 1990).

Manuring was simply in the form of animal droppings. The practice adopted by the Dogana diluted the excessively acidic droppings with urine: 
"When we make use of the term fold, as applied to the fertilizing effect of sheep pent upon land, we do not mean to convey an idea merely of the forces they leave behind them, in this case, but also of the urine, the trampling, and perhaps of the perspiration, and the warmth, communicated to the soil by the practice of folding" (Allison, 1957; Marshall 1795; Youatt, 1869). The combination produced manure called tahe, which considerably increased the productivity of the soil; the integration of grazing land and wheat fields added nitrogen to the soil. If $75 \%$ of the land was used for grazing (leaving $25 \%$ for crops) the yields were very high (over 27.5 bushels per acre). A slight increase in the amount of cultivated land (from 25 to $40 \%$, leaving $60 \%$ for grazing land) causes a sharp fall in yield, to 16.5 bushels per acre. And not only that: the soil begins to lose fertility and within 15 years the yield falls to just $20 \%$ (Shiel, 1991, p. 73; Newman, 2002). Hence, the system of fertilization and leaving cornfields fallow maintained the fertility of the soil long before chemical fertilizers were invented (Hall, 1909, p. 197).

In England, various regions had this or a similar kind of system according to the specific case and rights of land ownership. Important agricultural regions of England used sheep manure to improve soil fertility. In East Anglia fold-course rights of aristocratic origin determined the grazing of sheep on fallow fields, and this became a general practice for farms even without livestock. In east Yorkshire, the use of sheep manure to fertilize fields was not an obligation to the landowner but a choice of the farmer: the sheep grazed in the hills during the day and at night were taken to fallow fields. In Hertfordshire, numerous large flocks with hundreds of sheep were kept not so much for their wool as their droppings. Community grazing lands were used for wheat by rotation, with very high yields (Thirsk, 1967a, pp. 33, 44, 51). It is evident that the efficient utilization of manure due to the periodic alternation of grazing and tilling within the same field determined a crucial change that made a significant improvement to farmland in England well before the agricultural revolution of the late modern age. (Kitsikopoulos, 2004, p. 462)

Within this context, the opposition between sheep farming and growing cereals became a complex matter: "It may be safely assumed that sheep's dung increased of value in period of rising grain prices, and in areas where the lightness of the arable land necessitated heavy applications of manure, as in the sheep-wheat regions of Norflok and Wiltshire, sheep numbers may be maintained, and even increased in spite of a contraction in the demand for wool" (Bowden, 1967, p. 642).

In the system of the Dogana in the fifteenth century, the situation was the same: sheep-farming through leaving fields otherwise used for wheat fallow for the purpose of reintegrating the soil" (Marino, 1998b, p. 58). The association modified the role and value of working capital: sheep had a dual role, for the production of wool and the production of manure.

However, the association created by the Dogana had some specific fea- 
tures that enhanced its efficiency. To create the required synergy between sheep-farming and crop growing, integration on a massive scale was required, practically throughout the mainland Southern Italy. The heart of the system was in Capitanata (corresponding more or less to the province of Foggia today, with some additional territory) the area included in the Dogana extended along the Adriatic coastline (what today are the regions of Abruzzo, Molise and Puglia), and much of Basilicata and even portions of Campania. To reach an economically efficient integration, the factors of production needed to be used flexibly. As already stated, the role of the State did not prevent market forces from operating freely. The Crown supplied goods and services that encouraged trade: it was responsible for planning, provided the land either directly or through the barons for partial use and ensured that the factors of production and products could be moved, enforcing the contracts between the parties. These elements provided a stable framework in the medium and long run. The role of the state was not as so often described by historiography: not only and not so much a predator of financial resources through heavy taxation, but above all the prime mover of a supra-regional market area (Delano, 1979; Violante 2009).

It was only within a deep and coherent process of transformation that the complementary nature of wool and wheat production could become the basis for the economy of mainland Southern Italy. The system was enshrined in law in 1551, recognizing the rights of the farmers leasing the land for crops and ensuring that only fields that had been fertilized by sheep manure in the Dogana system could be sown for new crops (De Dominicis, 1781, p. 110).

The law specified exactly how the association between wool and wheat production was to be technically achieved: the land destined for crop growing was to be two quarters sown, one quarter left throughout the year for grazing and one quarter used for a shorter period as grazing land - from the start of November to January 17th (Ageta, 1692, pp. 124-126). The regulations of 1551 were clearly based on the cadastral survey carried out in 1549 and provide an excellent opportunity to analyze the complementary wool/wheat system in more detail.

Table 1 gives at least a rough idea of the framework managed by the Dogana: the data refers to the general locations to which most of the sheep were allocated.

It seems evident that the locations were of different size, fertility and ratio between cultivated and grazing land. Each location catered for both types of user: corn growers and sheep farmers. Each had a permanently assigned territory; however, the borders between one farmland and the next could be legally violated. This solution was enshrined in law; the number of sheep that could be allocated based on the amount of fallow land contributed to the total number of sheep the overall extension of land could handle during the stay on the Tavoliere (Marino, 1998). 
The procedure for allocating the portions of land to the flocks shows not only an unexpected ability to measure the area but also an understanding of the potential fertility of the soil. Table 1 shows how 23 general locations were characterized by 4 different levels of fertility of the grazing land, expressed as the number of sheep per carro. The table also highlights the division into grazing land and land used for other purposes (mainly for crops). If we look in detail at one location, we can see the type of ratio between grazing land and farmland for crops. Let's take an imaginary location (in terms of size only), covering 100 carri, divided exactly in two, half for grazing land, half for crops. In addition to the 50 carri for grazing land, the sheep could also use part of the land for crops (meaning for crops or left fallow) and the land set aside permanently for the grazing of work animals according to the following proportions: 20 carri for cultivation, 20 uncultivated and 10 for work animals. If the 20 carri left fallow, 10 could be used for the grazing of sheep at any time and 10 could be used for the sheep in the months of November and December, and was then to be left unused until the next sowing (Marino 1992). The grass in the fields left fallow was therefore calculated with the grazing land with a dual discount (the fallow land fed half the number of sheep per unit of size, and the size of the fallow land was based on two thirds of the total, because of the exclusion of half of the land for several months). To calculate the actual number of sheep, a coefficient was needed for the fertility of the land $(10,11,12$ or 13 carri per 1000 sheep). If our imaginary location is very fertile it will be able to handle 2000 sheep on grazing land and another 666 on the land left fallow. This is the result of calculating 2/3 of 20 carri left fallow, dividing by the coefficient of fertility for the fields left fallow. If the coefficient of fertility is low, the total is 2060 sheep (1538 on the grazing land and 512 on fallow land). The benefit to the fallow land of the presence of the sheep is evident.

To summarize the system used by the Dogana, the following equation shows the calculation that was made:

$$
N=P \times \frac{1000}{C F}+C \times \frac{1}{2} \times \frac{1}{2} \times \frac{2}{3} \times \frac{1000}{C F}=\left(P+C \times \frac{1}{6}\right) \times \frac{1000}{C F}
$$

where $N$ is the number of sheep, $P$ area of grazing land, $C$ the area of land for crops, $C F$ is the coefficient of fertility

The 4-year rotation in Puglia (see table 2) lengthened the time for crop growing and for leaving fields fallow from one to two years. The association of crop growing and sheep farming became a stable feature of the management of the land and of the tax system: the sheep fed on the grass from the land left fallow added to the number of sheep that could be catered for.

Quite aside from the technical questions, this procedure had a political significance: to guarantee transparency and fairness in the allocation of the land, treating large and small sheep farmers, large and small wheat growers, alike. The procedure did not prevent conflicts from arising but established the rules for settling the disputes, based on confidence in the system. To 
Table 1 - Extension, Pasture and Sheep for Each Single General Location Following the Data of "Reintegra" (1549)

\begin{tabular}{lcccccc}
\hline \hline & Location & $\begin{array}{c}\text { Extension } \\
\text { (in carri) }\end{array}$ & Farming (C) & Pasture (P) & CF* & Sheepn. \\
\hline 01 & Trinità & 722 & 324 & 348 & 10 & 39674 \\
02 & Orta & 377 & 144 & 233 & 10 & 25272 \\
03 & Ordona & 326 & 119 & 207 & 10 & 23018 \\
04 & Candela & 510 & 246 & 264 & 10 & 29875 \\
05 & Canosa & 1303 & 692 & 611 & 12 & 52585 \\
06 & Salpi & 674 & 144 & 530 & 10 & 55067 \\
07 & Cornito & 416 & 169 & 247 & 11 & 24500 \\
08 & Salsola & 307 & 149 & 158 & 10 & 17835 \\
09 & S. Giuliano & 272 & 145 & 127 & 11 & 13122 \\
10 & Camarda & 96 & 48 & 48 & 11 & 4933 \\
11 & Tressanti & 388 & 162 & 226 & 10 & 24693 \\
12 & F. d'Ascoli & 404 & 181 & 223 & 12 & 20342 \\
13 & Pontalbanito & 424 & 141 & 283 & 11 & 30730 \\
14 & Candelaro & 1129 & 498 & 631 & 10 & 70097 \\
15 & Castiglione & 1211 & 612 & 599 & 10 & 61895 \\
16 & Arignano & 678 & 299 & 379 & 11 & 41820 \\
17 & Casalnuovo & 996 & 530 & 466 & 10 & 51080 \\
18 & Apricena & 395 & 164 & 231 & 13 & 19211 \\
19 & Lesina & 274 & 85 & 189 & 13 & 15350 \\
\hline 20 & S. Andrea & 154 & 72 & 82 & 10 & 10380 \\
21 & Guardiola & 837 & 252 & 585 & 13 & 51209 \\
22 & Cave & 296 & 12 & 284 & 13 & 22022 \\
\hline 23 & Andria & 530 & 0 & 530 & 13 & 40000 \\
\hline \hline
\end{tabular}

Source: Coda 1666.

$\left(^{*}\right)$ Coefficient of fertility: pasture necessary to feed 1.000 sheep (in carri).

Table 2 - Rotation in the "Masserie di Portata" in a Solar Year

\begin{tabular}{|c|c|c|c|c|c|}
\hline Month & 1st Year & $2^{\text {nd }}$ Year & $3^{\text {rd }}$ Year & $4^{\text {th }}$ Year & $5^{\text {th }}$ Year \\
\hline January & & Crop & Crop & Pasture & Rest \\
\hline February & & Crop & Crop & Pasture & Rest \\
\hline March & & Crop & Crop & Pasture & Rest \\
\hline April & & Crop & Crop & Pasture & Rest \\
\hline May & & Crop & Crop & Pasture & Rest \\
\hline June & & Crop & Crop & Pasture & Rest \\
\hline July & & Crop & Pasture & Pasture & Rest \\
\hline August & & Crop & Pasture & Pasture & Rest \\
\hline September & Crop & Crop & Pasture & Pasture & \\
\hline October & Crop & Crop & Pasture & Pasture & \\
\hline November & Crop & Crop & Pasture & Pasture & \\
\hline December & Crop & Crop & Pasture & Pasture & \\
\hline
\end{tabular}

encourage the farmers to take part in the system, incentives were offered in the form of insurance against the risks of losses and climatic events. If the yield was low or animals died the entire system was threatened. Therefore the Dogana took over this risk by discounting the dead animals, introducing 
"a tax consideration for sheep killed in the harsh winter" (Marino, 1988b, p. 25). The farmers who leased the land for the production of corn benefited from a similar procedure, with discounts on the lease proportional to the fall in the recorded productivity (Di Stefano, 1731, pp. 221-220).

An analysis of the way the economic institution worked in concrete terms shows in-depth the relations between production and commercial activities. The Dogana had a direct effect on the management of land and an indirect effect on the national and international wool and grain markets.

\section{A Simple Analytical Model}

Assuming the land can be used for the production of one of two goods: wheat and wool and, in particular, for simplicity's sake, that if the best technology available is used, one unit of land (for example a hectare) can produce $k_{G}$ units of grain or $k_{L}$ units of wool. This means that when the decision is taken to allocate a certain quantity of land for the production of grain rather than wool, for every unit of grain produced $k$ units of wool are forfeited, where $k=k_{L} / k_{G}$. This ratio is the marginal rate of technical substitution $(M R T S)$ which indicates to what extent a factor of production can be replaced with another, i.e. how many units of one factor of production are forfeited in order to obtain one more unit of another factor of production, with unaltered output. Let us use $G$ to indicate the quantity of grain produced and $L$ for the quantity of wool, in terms of the quantity produced we obtain $L=k \times G$.

In a perfectly competitive market, the above hypotheses mean that the ratio between the prices of grain and wool is equal to $k$. Normalizing the price of grain $p_{G}$ to 1 , the price of wool $p_{L}$ becomes $1 / \mathrm{k}$. The ratio of $\mathrm{p}_{G} / \mathrm{p}_{L}$ is therefore equal to $k$.

With these hypotheses we can compare three alternatives: the production of wheat only, the production of wool only and the production of both. The third alternative is preferable for two different reasons related to respectively: 1) the ability to use fallow land for grazing, and 2) the flexibility of production based on fluctuations in international prices. Let us examine the two effects separately.

We can calculate the value of production in the following four cases:

a) use of land for the production of grain;

b) use of land for the production of wool;

c) use of part of the land $b$ for the production of wheat and part of the land $(1-b)$ for the production of wool (with $0<b<1$ );

d) use of part of the land $b$ for the production of wheat and part of the land $(1-b)$ for the production of wool using the fallow land for grazing. 
It is important to emphasize that the crucial difference between cases a), b) and c) and case d) is the use of the fallow land for grazing in the latter.

In case a) the value of production (which we will call $V$ ) is equal to:

$$
V_{a}=p_{G} G=G
$$

In case b) on the other hand, we have:

$$
V_{b}=p_{L} L=L / k=k G / k=G
$$

In case c) we have:

$$
\begin{aligned}
V_{c} & =b p_{G} G+(1-b) p_{L} L=b G+(1-b) L / k \\
& =b G+(1-b) k G / k=b G+(1-b) G=G
\end{aligned}
$$

In case $\mathrm{d}$ ), assuming that the amount of land left fallow is $m$ (with $0<m<$ 1) and, for simplicity's sake, that it has the same productivity as grazing land, $\sqrt{2}$ we obtain:

$$
\begin{aligned}
V_{d} & =b p_{G} G+(1-b) p_{L} L+b m p_{L} L=b G+[(1-b)+b m] L / k \\
& =b G+[(1-b)+b m] k G / k=G+b m G]^{3}
\end{aligned}
$$

Comparing these four alternatives it is clear that the value of production is the same in first three cases, but the alternative of using land for the production of both wheat and wool, with land left fallow used for grazing, leads to higher productivity. This is the first of the benefits created by the system used in the Kingdom of Naples.

Let us now try to adapt the model to the evidence available for 1549 to see its practical effects. The choice of the year has three different causes: the first is that archive data is sufficient for the reconstruction, the second is that it was the year of the publication of the results of the general reintegration of the Tavoliere under Francisco Revertera, aimed at re-establishing the exact proportion of land assigned for grazing and for cereals. Thirdly, 1549 was a year unaffected by external factors such as epidemics, famine or war.

We use an average yield from wheat seed of 1:4 (clearly lower than the real yields for the Tavoliere, which were obtained only through the fertilization of the land by sheep droppings). Given that the yield of the seed depended on the chemical and physical characteristics of the soil, the contours of the land and, last but not least, the organization of work, the yield of grain in the Kingdom of Naples varied enormously from province to province; for our purposes, we have adopted the average yield over the entire kingdom. ${ }^{4}$

Given that different types of wool were produced and quantities and prices also varied, an average of 2.5 pounds per sheep is used. This figure

${ }^{2}$ It can be shown that the results apply even without this simplification.

4 The following yields were reported: 1:2 in Catanzaro; Abruzzo Ultra 1:3.6, A. Lepre, Produzione e mercato: le crisi della prima metà dell'Ottocento in A. Massafra, Il Mezzogiorno preunitario: economia, società e istituzioni, Bari, 1988, pp. 124 and following. For Molise, 
was obtained by dividing the overall quantity of wool produced by the Dogana, as registered during the annual market in Foggia, the only market for the sale of wool, (Marino, 1988, p. 102), by the number of sheep grazing on the land.

A report sent in 1549 by the viceroy of Naples to the Consejo de Estado in Madrid, relating to the production of grain in the individual provinces of the Kingdom of Naples and the Capitanata province, shows 12,439 carra of grain produced, equal to 447,804 tomoli. ${ }^{5}$ This figure refers to an area larger than just the Dogana for the grazing of sheep - but it is the closest figure we have for the present purposes. Rather than using a grain production appraisal we adopted a proxy data extracted by a governmental official data sheet.

In terms of wool production, the number of sheep was taken from the registers or squarciafogli of the Dogana for the purposes of assigning the grazing land. According to the data for 1549, grazing land was allocated to flocks with $1,149,021$ sheep, corresponding to a production of 2,872,552 pounds (Marino, 1988b, Appendix D).

Based on the above, we can make the following calculations:

One hectare of land in the Tavoliere could produce 14.69 tomoli of grain $=K_{G}$;

One hectare of land in the Tavoliere could produce 8.5 pounds of wool $=K_{L}$;

The marginal rate of technical substitution (MRTS) between the two products $k=k_{L} / k_{G}=8.5 / 14.69=0.57$;

The quantity of grain produced $(G)$ in 1549 was 447,804 tomoli;

The quantity of wool produced $(L)$ in 1549 was $2,872,552$ pounds.

Now we can calculate the value of production $(V)$ in the four cases specified above:

in the mid-eithteenth century the yield was 1:5, A. Massafra, Campagne e territorio nel Mezzogiorno fra Settecento e Ottocento, Bari, 1984, p. 109. On the highly fertiel land of the Dogana, in Candela, the yield was 1:12. On the farmland of Canestrello, between 1519 and 1719 the average yield was 1:4.5, S. Zotta, Rapporti di produzione e cicli produttivi in regime di autoconsumo e di production speculativa. Le vicende agrarie dello «Stato» di Melfi nel lungo periodo (1530-1730), in A. Massafra (editor), Problemi di storia delle campagne meridionali nell'età moderna e contemporanea, Bari, 1981, pp. 221 and following. In Forenza in the early seventeenth century the yield was 1:5.1. Silvio Zotta notes that in bad years the yields were sometimes as low as 3:1. S. Zotta, Momenti e problemi di una crisi agraria in uni "stato" feudale napoletano (1585-1615), in «Mélanges de l'Ecole française de Rome, Moyen-Age, Temps modernes», vol. 90, 1978, pp. 726-734.

5 Archivo General de Simancas, Estado, Legajo 1030, Lista dela Informcion q dan los governadores de las provj:tias del grano q se alla en ellas. 
a) use of al the land for the production of wheat:

$V_{a}=p_{G} G=G$

$\Rightarrow$ based on the above figures, we obtain: $V a=1 \times 447804=447,804$

b) use of all the land for the production of wool:

$V_{b}=p_{L} L=L / k=k G / k=G$

$\Rightarrow$ based on the above figures, we obtain: $V_{b}=447,804$

c) use of a portion of land $b$ for the production of wheat and a portion

$(1-b)$ for the production of wool (with $0<b<1$ ):

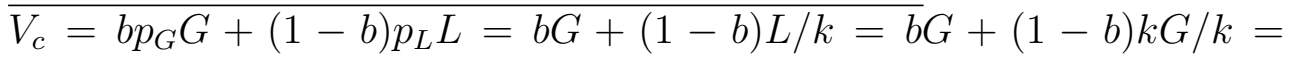
$b G+(1-b) G=G$

$\Rightarrow$ where $b=0.5$ from the above figures we obtain: $V_{c}=447,804$

d) use of a portion $\mathrm{b}$ of the land for the production of wheat and a portion $(1-b)$ for the production of wool, using the fallow land for grazing: $\overline{V_{d}}=b p_{G} G+(1-b) p_{L} L+b m p_{L} L=b G+[(1-b)+b m] L / k=b G+[(1-$ $b)+b m] k G / k=G+b m G$

Assuming the amount of fallow land $m$ (with $0<m<1$ ) is 0.5 and that its productivity is the same as that of the grazing land, we obtain: $V d=$ 559,775 .

Let us now posit the existence of an international market for the sale of our products. We will call the prices of the products on the international market $p_{i G}$ and $p_{i L}$. We can now see what happens to the three values $V_{a}, V_{b}$ e $V_{c}$ according to various scenarios of international versus internal prices. ${ }^{6}$

If $p_{i G} / p_{i L}=k$, as above, the value of production in cases a), b) and c) is the same.

If, on the other hand, $p_{i G} / p_{i L}>k$, the value of production in case a) is higher than case c) which is higher than case b).

Finally, if $p_{i G} / p_{i L}<k$, the value of production in case $\mathrm{b}$ ) is higher than for case $c$ ) which is higher than for case a).

Let us assume that the international price fluctuates around the internal price, i.e. is sometimes higher and sometimes lower. In cases a) and b) the economy is directly affected with the value of production rising or falling on the basis of the international price, without production being in any way able to offset the times of low prices.

In case c), on the other hand, it is possible to react to the change in price gradually modifying (i.e. maintaining the practice of alternating the use of land for grazing and for growing wheat) the ratio of the land dedicated to producing wool and the land used for the production of wheat. In particular, the value of parameter $b$ can be increased when the price of wheat is

6 Case d) is not included in order to exclude the effect of using the fallow land for grazing, as already analyzed. 
high, and reduced when the price falls. This gives, on average, a higher production value, producing greater overall wealth for the economy. This result is determined by the choice of the "mixed" production model, in which both goods are produced.

\section{Conclusions}

The long history of the Dogana delle Pecore, for the modern age at least, is the story of a general learning process (knowing how) by the actors involved. Process based on the active involvement of the same players (crown, farmers, sheep owners, land owners) obtained by the action on property rights and the possibility of a gradual expansion of the Dogana's territory on the basis of the production trends. The peculiarity of the Dogana model, in the Kingdom of Naples, includes the uniqueness of active complementarity between pasture and grain growth respect to the Castilian Mesta and other existing models of transhumance organization in Italy during modern age. The dynamic complementarity of the wool and wheat production represented an important resource for adapting the economy of the Kingdom to the different phases of the international economic cycle. The data from the management of the Dogana delle Pecore highlight a model of efficient management of land as a factor of production. The reform of the Dogana system, proposed by the Neapolitan Illuministi of the Eighteenth century and actually introduced by the French in 1806, proved to be a disastrous choice because of the development project that formed the basis did not consider the conditions of the economic environment. 


\section{References}

Acemoglu, D., Robinson, J., 2010. The Role of Institutions in Growth and Development. Review of Economics and Institutions 1, 1-33. doi:10.5202/rei.v1i2.14

Ageta, N.G., 1692. Annotationes pro regio aerario ad supremi regiae camerae summariae senatus regni Neapolis decisiones per luculentos tractatus, et quaestiones ad rem fiscalem attinentes. Vol. III, Vocula, Napoli.

Allison, K.J., 1957. The Sheep, Corn Husbandry of Norfolk in the Sixteenth and Seventeenth Centuries. The Agricultural History Review XX, 16-30.

Bailey, M., 1990. Sand into Gold: the Evolution of the Foldcourse System in west Suffolk, 1200-1600. The Agricultural History Review 38, 40-57.

Bowden, P., 1967. Agricultural Prices, Farm Profits, and Rents. In: Finberg, H., (ed.), The Agrarian History of England and Wales. Cambridge University Press, Cambridge, vol. 4 (1500-1650).

Carrier, E.H., 1932. Water and Grass. A Study in the Pastoral Economy of Southern Europe. Christofers, London.

Cazzola, F., 1998. Ovinos, transhumancia y lana en Italia desde la Edad Media hasta la Edad Moderna. In: Ruiz Martin, F., Garcia Sanz, A., (Eds.), Mesta, trashumancia y lana en la España Moderna. Fundación Duques de Soria, Crítica Grijalbo Mondadori, Barcelona.

Ciccolella, D., Guenzi, A., 2008. Scambi e gestione del rischio sui mercati locali e regionali. Il contratto alla voce nel Mezzogiorno in età moderna. Storia economica 1, 41-79.

Cleary, M., Delano Smith, C., 1990. Transhumance reviewed: past and present practices in France and Italy. Rivista di Studi Liguri LVI, 21-37.

Croce, B., 1917. La Spagna nella vita italiana. Laterza, Bari.

De Dominicis F.N., 1781. Lo stato politico, ed economico della dogana della mena delle pecore di Puglia. Flauto, Napoli.

Delano Smith, C., 1979. Western Mediterranean Europe : a historical geography of Italy, Spain and southern France since the Neolithic. Academic Press, London.

Del Treppo, M., 1984. Agricoltura e transumanza in Puglia nei secoli XIIIXVI: conflitto o integrazione?. In: Guarducci, A., (ed.), Agricoltura e trasformazione dell'ambiente. Secoli XIII-XVIII. Le Monnier, Firenze.

Di Stefano, S., 1731. La Ragion pastorale. Roselli, Napoli.

Drelichman, M., 2009. License to till: The privileges of the Spanish Mesta as a case of second-best institutions. Explorations in Economic History 46, 220-240. doi:10.1016/j.eeh.2008.10.001 
Ekelund, R.B., Donald, R.S., Tollison, R.D., 1997. Rent Seeking and Property Rights' Assignments as a Process: the Mesta Cartel of Medieval-Mercantile Spain. Journal of European Economic History 26, 9-35.

Finberg, H., (ed.), 1967. The Agrarian History on England and Wales. vol. IV, Cambridge University Press, Cambridge.

Forni, N., 2000. Common property regimes: origins and implications of the theoretical debate. Land reform, land settlement and cooperatives 1, 29-41.

Garcia Martin, P., 1990. La Mesta. Historia, Madrid.

Grigg, D.B., 1976. The agricultural systems of the world: an evolutionary approach. Cambridge University Press, Cambridge.

Hall, A.D., 1909. Fertilisers and Manures. Murray, London. doi:10.5962/bhl.title.32608

Kitsikopoulos, H., 2004. Convertible Husbandry vs. Regular Common Fields: A Model on the Relative Efficiency of Medieval Field Systems. The Journal of Economic History 64, 462-499. doi:10.1017/S0022050704002761

Kleinhenz, C., 2004. Medieval Italy: an encyclopaedia. Vol. 2 L to Z, Routledge, New York.

Klein, J., 1920. The Mesta: a study in Spanish economic history 1273-1836. Harvard University Press, Cambridge (Mass.). doi:10.4159/harvard.9780674337206

Lewin, K., 1948. Conduct, knowledge and acceptance of new values. In: Lewin, G.W., (ed.), Resolving social conflicts. selected papers on group dynamics. Harper \& Row, New York.

Marin Barriguete, F., 1998. El derecho de posesion. In: Ruiz Martin, F., Garcia Sanz, A., (Eds.), Mesta, trashumancia y lana en la España Moderna. Fundación Duques de Soria, Crítica Grijalbo Mondadori, Barcelona.

Marino, J., 1988a. Wheat and Wool in the Dogana of Foggia. An Equilibrium Model for Early Modern European Economic History. Melanges de 1'Ecole franciase de Rome. Moyen-Age, Temps modernes 100, 871-892.

Marino, J., 1988b. Pastoral economics in the Kingdom of Naples. Johns Hopkins University Press, Baltimore.

Marshall, M., 1795. The rural economy of Norfolk, comprising the management of lands estates and the present practice of husbandry in that County. Vol. 1, Nicol, London.

Massafra, A., 1984. Campagne e territorio nel Mezzogiorno fra Settecento e Ottocento. Dedalo, Bari.

Massafra, A., 1988. Il Mezzogiorno preunitario: economia, società e istituzioni. Dedalo, Bari. 
McNeill, J.R., 1992. The mountains of the Mediterranean World: an environmental history. Cambridge University Press, Cambridge. doi:10.1017/CBO9780511529023

Mørch, H., 1987. Rural landscapes in Puglia. On the functional relationship between agriculture and natural resources. Geografisk Tidsskrift 87, 36-42. doi:10.1080/00167223.1987.10649239

Mordant, J., 1761. The complete steward or the duty of a steward to his lord. Vol. 1, Sandby, London.

Newman, E.J., 2002. Medieval sheep-corn farming: how much grain yeld could each sheep support?. The Agricultural History Review 50, 164-180.

Nugent, J. B., Sánchez, N., 1989. The Efficiency of the Mesta: A Parable. Explorations in Economic History 26, 261-284. doi:10.1016/00144983(89)90022-3

Pinto-Correja, T., Vos, W., 2004. Multifunctionality in Mediterranean Landscapes. In: Jongman, G., (ed.), The New Dimensions of the European Landscapes. Springer, Dordrecht. doi:10.1007/978-1-4020-2911-0_10

Renda, F., 1974. Bernardo Tanucci e i beni dei Gesuiti in Sicilia. Edizioni di Storia e Letteratura, Roma.

Ruiz Martin, F., (ed.), 1998. Mesta, Transhumancia y lana en la Espana moderna. Critica, Barcelona.

Russo, S., Salvemini, B., 2007. Ragion pastorale, ragion di stato. Spazi dell'allevamento e spazi dei poteri nell'Italia di età moderna. Viella, Roma.

Ryder, A., 1976. The Kingodm of Naples Under Alfonso the Magnanimous. The Making, of a Modern State. Clarendon, Oxford.

Sakellariou, E., 2012. Southern Italy in the Late Middle Ages: Demographic, Institutional and economic change in the Kingdom of Naples. Brill, Leiden.

Shiel, R.S., 1991. Improving soil productivity in the pre-fertiliser era. In: Campbell, B., Overton, M., (eds.), Land, labour and livestock: historical studies in European agricultural productivity. Manchester University Press, Manchester.

Sorre, M., 1913. Les Pyrenees Mediterraneennes: etude de geographie biologique. Colin, Paris.

Swinburne, H., 1783. Travels in the Two Sicilies in the Years 1777, 1778, 1779, and 1780. vol. 1, Elmsly, London.

Thirsk, J., 1967a, The Farming Regions of England. In: Finberg, H., (ed.), The Agrarian History of England and Wales, 1500-1640. Vol. 4, Cambridge University Press, Cambridge, 1-112.

Thirsk J. 1967b, Farming Techniques. Enclosing and Engrossing. In: Finberg, H., (ed.), The Agrarian History of England and Wales, 1500-1640. Vol. 4, Cambridge University Press, Cambridge, 161-255. 
Violante, F., 2009. Il re, il contadino, il pastore : la grande masseria di Lucera e la Dogana delle pecore di Foggia tra il XV e XVI secolo. Edipuglia, Bari.

Youatt, W., 1869. Sheep, their breeds, management, and diseases. Simpkin \& Marshall, London.

Young, A., 1804. General View of the agriculture of the County of Norfolk. Mc Millan, London.

Zotta, S., 1981. Rapporti di produzione e cicli produttivi in regime di autoconsumo e di production speculativa. Le vicende agrarie dello $\ll$ Stato $\gg$ di Melfi nel lungo periodo (1530-1730). In: Massafra, A., (Ed.), Problemi di storia delle campagne meridionali nell'età moderna e contemporanea. Dedalo, Bari.

Zotta, S., 1978. Momenti e problemi di una crisi agraria in uno "stato" feudale napoletano (1585-1615). Mélanges de l'Ecole française de Rome, MoyenAge, Temps modernes 90, 726-734.34. 